\title{
Computerized method for estimation of ultimate load of piles
}

\author{
Basheer Younis ${ }^{1 *}$, Khudhair Thamer ${ }^{2}$, and Firas Kazimahomedov ${ }^{1}$ \\ ${ }^{1}$ Kharkiv National University of Civil Engineering and Architecture, Department of Building \\ Materials and Products, 61002 Sumska st, 40, Kharkiv, Ukraine \\ ${ }^{2}$ Al-Maaref University College, 330 Rmadi, Anbar, Iraq
}

\begin{abstract}
A new method was established to estimate the ultimate load, which is utilized in the assessment of pile test. In the present study twenty five reports of failure test piles $(28.5 \times 28.5 \mathrm{~cm}$ in dimensions, $12 \mathrm{~m}$ in depth and the working load was 40 ton) of Um-Alqura Mosque project were studied in according to their loading and settlement. The (mean \pm SD) of the pile settlement for each load of all piles studied were determined, and the results obtained were utilized to generate the equation that correlates between the load and settlement using (4th degree polynomial fit graph). The equation obtained was applied to estimate the ultimate load for the maximum settlement ( $10 \%$ of the pile diameter). The estimated ultimate load (130 ton) in the present study was compared with the ultimate load (132 ton), which was determined previously using (Fellenius and Decourt presentation, 2001). The deviation between the ultimate load of the previous and the present method was $(1.5 \%)$, but the present method depends on two working load, so it saves time and efforts and suitable to implement in the assessment of the test pile.
\end{abstract}

\section{Introduction}

A pile is structural member of timber, concrete or steel used to transmit structure load through water soft soil to a good bearing stratum by means end bearing resistance and skin friction. The piles can be classified according to pile material (timber, steel and composite piles), their effect on an adjacent soil (non displacement, displacement piles), and according to method of execution (driven and bored piles) [1-6]. The purpose of the static load test is to find the allowable load, which is established by dividing the ultimate load with a factor of safety. The factor of safety normally applied in the industry ranges from a low of 1.8 through a high of 2.5. The factor of safety is not a singular value applicable at all time. Its value depends on the desired freedom from unacceptable consequence of failure, as well as on the level of knowledge and control of the aspects influencing the variation of capacity at the pile. Most codes specify a single factor regardless of condition usually, frequently larger. There are many criterions in assessment the test pile and calculate the ultimate load. All the previous criterions extrapolated from later part of the load - settlement curve [7-10]. In the present study new equation was generated from the load - settlement curve to

\footnotetext{
* Corresponding author: docbasheer01@gmail.com
} 
estimate the ultimate load of pile which was related to the maximum settlement of piles utilizing (ASTMD 1143-1987-5.1) [11], and computer algorithms that concerning the graphic purpose.

\section{Materials and methods}

Twenty-five precast concrete piles test reports of (Um-Alqura Mosque project / Iraq) were studied $(2 \%$ of the total number of the executed piles). The piles were $(28.5 \times 28.5 \mathrm{~cm}$ and $12 \mathrm{~m}$ ) in dimensions and depth respectively. The piles were tested by (ASTM D1143-19875.1), and the working load of each pile was 40 ton.

The following tools were used in the pile test:

1. Kentledge (collection from the steel members).

2. Hydraulic jack.

3. Cell load.

4. Concrete block (collection from uniform concrete sections

5. Hydraulic pump and dial gage.

6. Gages for settlement reading.

7. References beam for settlement gages.

8. The survey equipments.

9. Bearing plate.

10. Crane and shovel.

In this study, new equation was established to estimate the ultimate load according to the following steps:

1. Determination of the mean settlement of all piles studied, listed in Table 1.

2. Draw the relation between load and mean settlement, (Fig. 1).

3. Determination of the equation that correlates between load and settlement utilizing curve expert program (4th degree polynomial fit graph).

4. The equation established is used to estimate the ultimate load that causes settlement of $(10 \%$ of the diameter of the piles studied $)$.

\section{Results}

The results obtained depend on practical results that were excluded from twenty-five pile test reports of the assessment of the piles studied. Table 1 showed the load up to double working load with the mean settlement for the each load of all piles studied.

The results that listed in Table 1 were utilized to generate Fig. 1, and the following equation was obtained:

$$
Y=0.026+0.0042 x-0.002 x^{2}+4.765 e-005 x^{3}-3.789 e-007 x^{4},
$$

The equation that mentioned above, was to estimate the ultimate load (that related to the maximum settlement not exceed $10 \%$ of the pile diameter).

The result obtained of the estimated ultimate load is compared with the calculated ultimate load of eight piles of the same project, using another method of assessment of pile test (depends on three working load) [12], the results are listed in Table 2, and shows that the deviation between the ultimate load of the present and the previous method does not exceed (1.67\%). 
Table 1. The load (ton) and settlement of the piles studied.

\begin{tabular}{|c|c|c|}
\hline Load (ton) & Settlement (mm) mean & \pm SD \\
\hline 0 & 0 & 0 \\
\hline 10 & 0.2344 & 0.16981 \\
\hline 20 & 0.5428 & 0.32027 \\
\hline 30 & 0.8796 & 0.51923 \\
\hline 40 & 1.2676 & 0.78756 \\
\hline 50 & 1.74 & 1.07943 \\
\hline 60 & 2.3864 & 1.57431 \\
\hline 70 & 3.1292 & 2.17814 \\
\hline 80 & 4.89 & 5.19013 \\
\hline
\end{tabular}

$* \mathrm{SD}=$ Standard deviation.

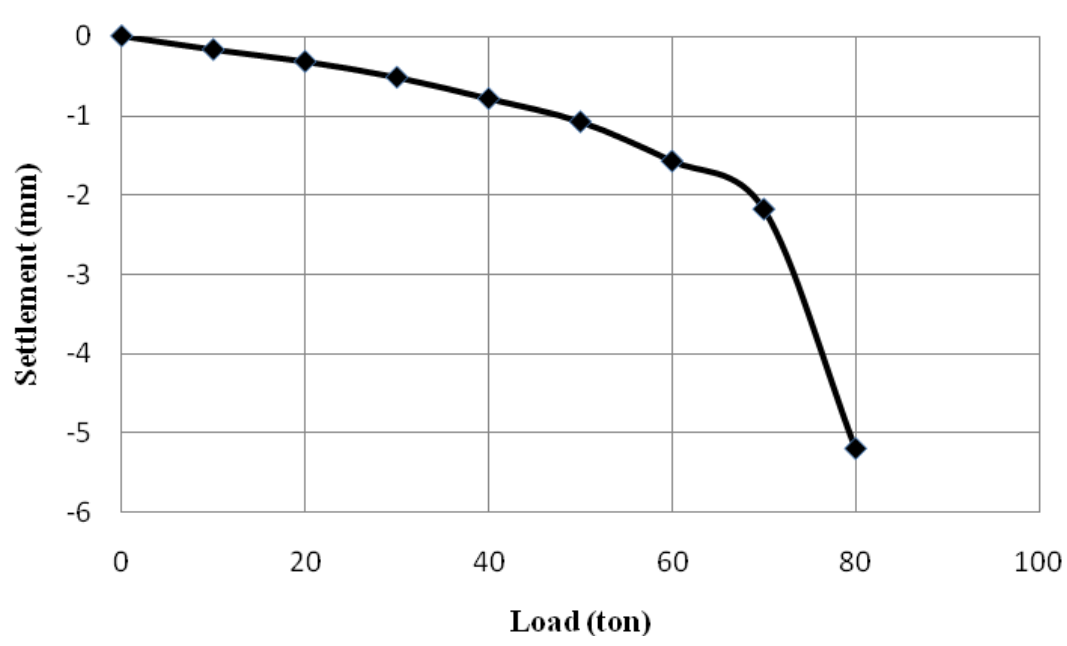

Fig. 1. Load - settlement curve of the piles studied.

Table 2. Comparison between the estimated ultimate load utilizing the present method and the method of (Fellenius and Decourt presentation, 2001).

\begin{tabular}{|c|c|c|c|}
\hline Methods & Working load (ton) & Ultimate load (ton) & $\begin{array}{c}\text { Deviation } \\
\text { (percent) }\end{array}$ \\
\hline Present method & $\begin{array}{c}\text { 2 working load } \\
\text { (80 ton) }\end{array}$ & 130.2 & $1.67 \%$ \\
\hline $\begin{array}{c}\text { Fellenius \&Decourt } \\
\text { method, 2001 }\end{array}$ & $\begin{array}{c}\text { 3 working load } \\
\text { (120 ton) }\end{array}$ & 132.0 & \\
\hline
\end{tabular}

\section{Discussion}

Many methods were applied in assessment of pile test. Such methods were arranged and used according to the types of piles, soils and the technique used. The advancement in this field added some new practical applications to the assessment of the pile test that depends on different facilities and equipments. The assessment methods of the pile test depend on work loading, value of settlement, and special technical management for pile loading, in according to the type of piles (precast, bored, timber, etc), types of soils, diameter of pile, 
depth of excavating, working load, geological properties, topographic properties and the nature of the material used in manufacturing of the piles. Also, all these methods of assessment of pile test depend on the final settlement of the executed piles that is not exceeded 10\% of the pile diameter, (Davisson, 1972, Hanssen, 1970, Decourt, 1999, Fellenius, 2001). In the present study to overcome all the parameters that effect on the assessment of the pile test, new equation was generated and applied in the assessment of piles that (previously tested and assessed as succeeded piles, by method of ASTMD1143-1987-5.1). The equation established was utilized to estimate the ultimate load of the piles studied and depends on the real load-settlement curve (two working load) that related to the maximum pile settlement, bearing capacity, skin friction, water content of soil, volume of the soil, that effect on the pile settlement. Also the present method was applied for two working load to save the time and efforts in the assessment of the executed piles. The comparison between the present method and the method of (Fellenius and Decourt presentation, 2001), showed that the deviation of the estimated ultimate load of the two method was not exceed (1.67\%). Also the applications of the present method in different projects and area will be used as reference for the future projects for soils of the same nature.

\section{Conclusions}

New method was established to estimate the ultimate load for assessment of pile test, utilizing computer programs for fitting load - settlement curve. The present method depends on two working load, concerning maximum settlement. The application of the present method will give new reference of ultimate load and settlement of different types of soils. So the present method save time and efforts and suitable to implement in the assessment of pile test.

\section{References}

1 J.E. Boweles, Foundation analysis and Design, (Second Edition, 1977)

2 BSI. CP2004, Code of practice-foundations, (1971)

3 B.H. Fellenius, Basics of Foundation Design, (Canada, 2009)

4 R. Rajapakse, Pile Design and Construction Rules of Thumb, (Elsevier, (2008)

5 ICE. Behaviour of piles, (London, 1971)

6 K. Karlsrud, PhD Thesis, (Trondheim, Norwegian University of Science and Technology, 2012)

7 M.T. Davisson, Proceedings Lecture Series, (Illinois Section American, 52 (1972)

8 J.B. Hansen. A Revised and Extended Formula for Bearing Capacity, Denmark, 28 (1970)

9 B. Fellenius, Geotechnical Engineering Journal of the SEAGS \& AGSSEA, 42 (2), 70-77 (2011)

10 B.H. Fellenius, Proceedings of the Deep Foundation Institute. Bearing capacity-a delusion, (Dearborn, Michigan, 1999)

11 ASTM D1143-87, 5.1. Testing Piles Under Static Axial Compressive load, (1987)

12 L Decourt, Felleniuse, Deep Foundation Institute. Extrapolation method, Fulcrum, (New Jersy, 2001) 